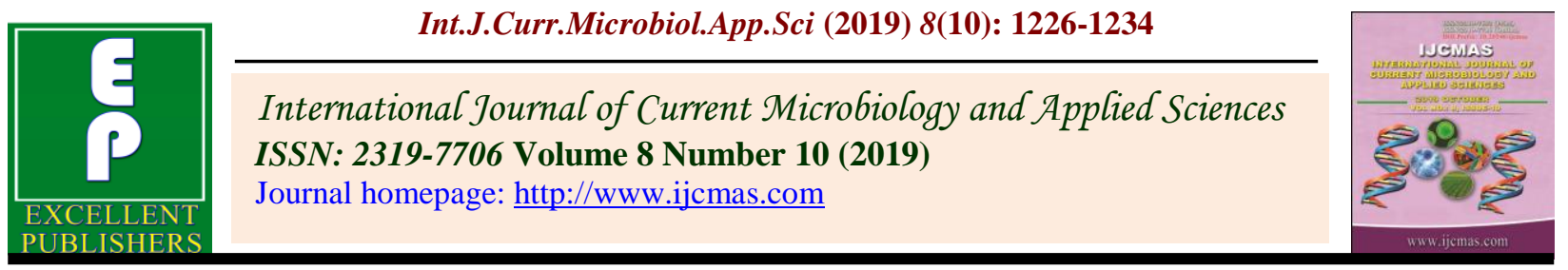

Original Research Article

https://doi.org/10.20546/ijcmas.2019.810.144

\title{
Effect of Zinc and Iron Fertilization on Yield, Nutrient Content and Uptake of Direct Sown Rice
}

\author{
S. Janardhan and I. Usha Rani* \\ Department of Soil Science and Agricultural Chemistry, Agricultural College, \\ Bapatla-Guntur-522 101, India \\ *Corresponding author
}

Keywords

N, P, K, Zn, Fe, Mn and $\mathrm{Cu}$ Content and Uptake

\section{Article Info}

Accepted:

10 September 2019

Available Online:

10 October 2019

A field experiment entitled "Response of Direct Sown Rice to Zinc and Iron Nutrition" was conducted at Agriculture College Farm, Bapatla, during kharif, 2017. The experiment was laid out in randomized block design (RBD) with seven treatments replicated thrice. The results revealed that, The nutrient content $(\mathrm{N}, \mathrm{P}, \mathrm{K}, \mathrm{Mn}$ and $\mathrm{Cu})$ of direct sown rice at tillering, panicle initiation and harvest was not significantly influenced by the treatments and zinc and iron contents were significantly influenced by the treatment that received RDF $+\mathrm{ZnSO}_{4} @ 50 \mathrm{~kg} \mathrm{ha}^{-1}+\mathrm{FeSO}_{4} @ 25 \mathrm{~kg} \mathrm{ha}^{-1}$ through soil application. Lower values of all the nutrients were recorded with RDF. Uptake of nutrients at tillering, panicle initiation and at harvest was markedly influenced by the treatment that receive $\mathrm{RDF}+\mathrm{ZnSO}_{4} @ 50$ $\mathrm{kg} \mathrm{ha}^{-1}+\mathrm{FeSO}_{4} @ 25 \mathrm{~kg} \mathrm{ha}^{-1}$ through soil application. While, lower values were recorded with RDF.

\section{Introduction}

Rice (Oryza sativa L.) is a staple food for more than one third of the world population (Zhao et al., 2011). In India, it is grown in an area of 44.1 million hectares with a production of 108.9 million tonnes and productivity of $2391 \mathrm{~kg} \mathrm{ha}^{-1}$. In Andhra Pradesh, it is grown in an area of 2.394 million hectare with a production of 7.24 million tonnes and productivity of $3022 \mathrm{~kg} \mathrm{ha}^{-1}$ (Ministry of
Agriculture, Govt. of India, 2016-17). In India, rice occupies one-quarter of the total cropped area contributing about 40 to 43 per cent of total food grain production and continues to play vital role in the national food security system (Viraktamath et al., 2011).

Direct seeding of rice (DSR) refers to the process of establishing the crop from seeds sown in the field rather than by transplanting seedlings from the nursery (Farooq et al., 
2011). Agriculture is the primary source of providing all nutrients required for crops and for human health, and fertilization is the key point of integrated nutrient management (INM) in agronomic approaches to enhance crop quality and quantity. Fertilization therefore, could be one of the sustainable and low cost strategies in improving $\mathrm{Fe}$ and $\mathrm{Zn}$ concentration in edible portions of staple food crops (Rengel et al., 1999).

Micronutrients, particularly zinc and iron have attained a great significance in today's intensive and exploitive agriculture which is aiming at higher crop productivity. The total iron and zinc content of Indian soils of varies from $0.8-1.96 \mathrm{mg} \mathrm{kg}^{-1}$ and $0.2-6.9 \mathrm{mg} \mathrm{kg}^{-1}$, respectively (Singh, 2009).

In direct seeding, availability of several nutrients including $\mathrm{N}, \mathrm{P}, \mathrm{S}$ and micronutrients such as $\mathrm{Zn}$ and $\mathrm{Fe}$, is likely to be a constraint. Nonetheless, farmers are inclining to adopt direct sown rice and the area under direct sown rice is increasing year after year. Keeping the point in view a field study was under taken to assess the effect of zinc and iron on nutrient content, uptake and yield of direct sown rice.

\section{Materials and Methods}

The experiment was conducted at the Agricultural College Farm, Bapatla situated in Krishna zone of Andhra Pradesh. The experiment was laid out in randomized block design with seven treatments replicated thrice. The treatments comprises of $\mathrm{T}_{1}$ - RDF (180:60 :40 N-P $\mathrm{O}_{2}-\mathrm{K}_{2} \mathrm{O}\left(\mathrm{kg} \mathrm{ha}^{-1}\right) ; \mathrm{T}_{2}-\mathrm{RDF}+\mathrm{ZnSO}_{4}$ @ 50 $\mathrm{kg} \mathrm{ha}^{-1}$ through soil application; $\mathrm{T}_{3}-\mathrm{RDF}$ $+\mathrm{FeSO}_{4} @ 25 \mathrm{~kg} \mathrm{ha}^{-1}$ through soil application; $\mathrm{T}_{4}-\mathrm{RDF}+\mathrm{ZnSO}_{4} @ 50 \mathrm{~kg} \mathrm{ha}^{-1}+\mathrm{FeSO}_{4} @ 25$ $\mathrm{kg} \mathrm{ha}^{-1}$ through soil application; $\mathrm{T}_{5}-\mathrm{RDF}+$ foliar spray of $\mathrm{ZnSO}_{4} @ 0.2 \%$ at 20 and 45 DAS; $\mathrm{T}_{6^{-}} \mathrm{RDF}+$ foliar spray of $\mathrm{FeSO}_{4} @$ $0.5 \%$ at 20 and $45 \mathrm{DAS} ; \mathrm{T}_{7}-\mathrm{RDF}+$ foliar spray of $\mathrm{ZnSO}_{4} @ 0.2 \%$ and $\mathrm{FeSO}_{4} @ 0.5 \%$ at 20 and 45 DAS. The variety used for the experiment is BPT 5204. For all the treatments at the time of sowing half of the recommended dose of nitrogen and full dose of $\mathrm{P}$ and $\mathrm{K}$ was applied. Remaining dose of nitrogen was applied 45 DAS. Urea, SSP \& MOP was used as a source of $\mathrm{N}, \mathrm{P}$ and $\mathrm{K} . \mathrm{ZnSO}_{4}$ was used as a source of zinc fertilizer and $\mathrm{FeSO}_{4}$ was used as a source of iron fertilizer. Foliar application was done at different growth stages such as 20 and 45 DAS. For foliar application $0.2 \%$ $\mathrm{ZnSO}_{4}$ and $0.5 \% \quad \mathrm{FeSO}_{4}$ solution was prepared.

The experimental soil was sandy clay in texture, neutral in reaction (7.48) and nonsaline $(0.53)$ in nature and low in organic carbon $(4.0 \mathrm{~g} / \mathrm{kg})$, low in available nitrogen $\left(224 \mathrm{~kg} \mathrm{ha}^{-1}\right)$, medium in available phosphorus $\left(38.8 \mathrm{~kg} \mathrm{ha}^{-1}\right)$ and medium in available potassium $\left(285 \mathrm{~kg} \mathrm{ha}^{-1}\right)$. Nutrient uptake $(\mathrm{kg}$ $\mathrm{ha}^{-1}$ ) by rice was calculated using the values of percent nutrient concentrations and dry matter production $\left(\mathrm{kg} \mathrm{ha}^{-1}\right)$

The plant samples collected at tillering, panicle initiation stage and harvest stage washed with dilute $\mathrm{HCl}$ and then with distilled water. The samples were shade dried initially and then oven dried at $60{ }^{\circ} \mathrm{C}$ temperature and powdered in willey mill and analyzed for various nutrients.

The nitrogen content in rice plants was estimated by micro Kjeldahl distillation method. One gram of powdered plant sample was taken in $150 \mathrm{ml}$ Erlenmeyer flask and digested with diacid mixture $\left(\mathrm{HNO}_{3}\right.$ and $\mathrm{HClO}_{4}$ in 9: 4 ratio). The sample digest was filtered through Whatman No. 42 filter paper by washing the residue with double glass distilled water till chloride free and made upto $100 \mathrm{~mL}$ volume and the clear extract was used for the determination of $\mathrm{P}, \mathrm{K}, \mathrm{Zn}, \mathrm{Fe}, \mathrm{Mn}$ and $\mathrm{Cu}$. 
Micronutrients Uptake (kg ha $\left.{ }^{-1}\right)$

$$
\begin{gathered}
\begin{array}{c}
\text { Nutrient content }\left(\mathrm{mg} \mathrm{kg}^{-1}\right) \\
\text { X Yield }\left(\mathrm{kg} \mathrm{ha}^{-1}\right)
\end{array} \\
100
\end{gathered}
$$

\section{Results and Discussion}

\section{Nutrient content (\%)}

Nutrient content (N, P and $\mathrm{K}$ ) at any stage of crop growth was not significantly influenced by zinc and iron fertilization (Table 1). The highest nitrogen content of $2.49,1.45,0.81$ and 1.86 per cent and the highest phosphorus content $(0.37,0.33,0.22$ and 0.44 per cent) at tillering, panicle initiation, in straw and grain at harvest, respectively), and the highest potassium content in straw 2.92, 2.50, 1.43 and 0.96 per cent at tillering, panicle initiation, straw and grain at harvest, respectively was observed with application of $\mathrm{RDF}+\mathrm{ZnSO}_{4} @$ $50 \mathrm{~kg} \mathrm{ha}^{-1}+\mathrm{FeSO}_{4} @ 25 \mathrm{~kg} \mathrm{ha}^{-1}$ through soil application and the lowest $\mathrm{N}, \mathrm{P}$ and $\mathrm{K}$ content was recorded in (RDF). The combined soil application of zinc and iron fertilization increased nitrogen content at tillering stage and later stages (at panicle initiation and harvest). The nitrogen content in rice straw was found to decrease from tillering stage to maturity with the maximum nitrogen content recorded at tillering in all treatments. This might be due to higher absorption of $\mathrm{N}$ by growing plants initially and also due to effect of increased dry matter production with growth (Keram et al., 2012).

The $\mathrm{P}$ content was found to decrease from tillering to maturity with maximum $\mathrm{P}$ content recorded at tillering stage. At harvest the phosphorus content in grain was higher as compared to that of straw, however, the zinc and iron fertilization did not affect the $\mathrm{P}$ content significantly in grain and straw of rice plant. The $\mathrm{P}$ content decreased from tillering to panicle initiation. It might be due to the dilution effect of nutrient. Similar findings were reported by Ghoneim et al., (2016) who, stated that $\mathrm{P}$ reacts with zinc in soil which reduces the translocation of zinc from roots to shoots and also imbalances the $\mathrm{P}: \mathrm{Zn}$ ratio in plant. The potassium content was found to decrease from tillering to maturity. Further it is also interesting to note that $\mathrm{K}$ content was higher in straw than grain of at harvesting stage rice as compared to $\mathrm{N}$ and $\mathrm{P}$, which indicated that rice straw is useful as a source of potassium.

\section{Micronutrient content $\left(\mathrm{mg} \mathrm{kg}^{-1}\right)$}

The maximum zinc and iron content at tillering, panicle initiation, straw and grain at harvest stage $\left(69,62,45\right.$ and $41 \mathrm{mg}$ of $\mathrm{Zn} \mathrm{kg}^{-1}$ and 466, 441, 431and $210 \mathrm{mg} \mathrm{Fe} \mathrm{kg}^{-1}$ ) was recorded under $\left(\mathrm{RDF}+\mathrm{ZnSO}_{4} @ 50 \mathrm{~kg} \mathrm{ha}^{-1}+\right.$ $\mathrm{FeSO}_{4} @ 25 \mathrm{~kg} \mathrm{ha}^{-1}$ through soil application). The minimum zinc and iron content $(54,47$, 27 and $22 \mathrm{mg} \mathrm{Zn} \mathrm{kg}^{-1}$ and 428, 415, 383 and $164 \mathrm{mg} \mathrm{Fe} \mathrm{kg}^{-1}$ ) was recorded with (RDF) (Table 2). With regard to Manganese and Copper content at all stages of crop growth was not significantly influenced by zinc and iron fertilization The results indicated that combined application of zinc and iron fertilization enhanced zinc and iron concentration at all stages of crop growth which was significantly superior to control. The results are in agreement with those of Tahir and Kausar (1994). The increase in content of iron might be due to more favourable conditions and continued flooding leading to the reduction of higher oxides and hydroxides of $\mathrm{Fe}$ into soluble form either through an increase in solubility in soil solution or possible stimulation of root activity. The results are in accordance with those of Antil et al., (1989). Soil application of higher level iron significantly increased iron content in straw and grain at harvest (Gohil et al., 2017). 
Table.1 Effect of zinc and iron fertilization on nitrogen, phosphorus and potassium content (\%) of direct sown rice

\begin{tabular}{|c|c|c|c|c|c|c|c|c|c|c|c|c|}
\hline \multirow[t]{3}{*}{ Treatments } & \multicolumn{4}{|c|}{ Nitrogen } & \multicolumn{4}{|c|}{ Phosphorus } & \multicolumn{4}{|c|}{ Potassium } \\
\hline & \multirow[t]{2}{*}{ Tillering } & \multirow{2}{*}{$\begin{array}{l}\text { Panicle } \\
\text { initiation }\end{array}$} & \multicolumn{2}{|c|}{ At harvest } & \multirow[t]{2}{*}{ Tillering } & \multirow{2}{*}{$\begin{array}{l}\text { Panicle } \\
\text { initiation }\end{array}$} & \multicolumn{2}{|c|}{ At harvest } & \multirow[t]{2}{*}{ Tillering } & \multirow{2}{*}{$\begin{array}{l}\text { Panicle } \\
\text { initiation }\end{array}$} & \multicolumn{2}{|c|}{ At harvest } \\
\hline & & & Grain & Straw & & & Grain & Straw & & & Grain & Straw \\
\hline $\mathbf{T}_{1}$ & 1.87 & 1.18 & 1.37 & 0.63 & 0.26 & 0.22 & 0.36 & 0.14 & 2.41 & 1.62 & 0.79 & 1.29 \\
\hline $\mathbf{T}_{2}$ & 2.31 & 1.35 & 1.77 & 0.75 & 0.32 & 0.29 & 0.39 & 0.19 & 2.85 & 1.96 & 0.86 & 1.38 \\
\hline $\mathbf{T}_{3}$ & 2.21 & 1.29 & 1.70 & 0.70 & 0.30 & 0.27 & 0.38 & 0.17 & 2.82 & 1.85 & 0.89 & 1.35 \\
\hline $\mathbf{T}_{4}$ & 2.49 & 1.45 & 1.86 & 0.81 & 0.37 & 0.33 & 0.44 & 0.22 & 2.92 & 2.50 & 0.96 & 1.43 \\
\hline $\mathbf{T}_{5}$ & 2.26 & 1.31 & 1.72 & 0.72 & 0.29 & 0.28 & 0.39 & 0.18 & 2.84 & 1.90 & 0.88 & 1.37 \\
\hline $\mathbf{T}_{6}$ & 2.19 & 1.28 & 1.69 & 0.69 & 0.34 & 0.27 & 0.38 & 0.17 & 2.80 & 1.82 & 0.84 & 1.33 \\
\hline $\mathbf{T}_{7}$ & 2.34 & 1.41 & 1.79 & 0.77 & 0.35 & 0.31 & 0.42 & 0.20 & 2.87 & 2.17 & 0.91 & 1.40 \\
\hline $\operatorname{S.Em}( \pm)$ & 0.14 & 0.07 & 0.11 & 0.03 & 0.02 & 0.02 & 0.02 & 0.01 & 0.10 & 0.11 & 0.05 & 0.05 \\
\hline CD $(0.05 \%)$ & NS & NS & $\mathrm{NS}$ & NS & NS & NS & NS & NS & $\mathrm{NS}$ & $\mathrm{NS}$ & NS & NS \\
\hline C.V(\%) & 11.12 & 9.48 & 11.54 & 9.23 & 13.27 & 14.56 & 11.36 & 14.79 & 6.50 & 10.12 & 11.23 & 6.35 \\
\hline
\end{tabular}




\section{Int.J.Curr.Microbiol.App.Sci (2019) 8(10): 1226-1234}

Table.2 Effect of zinc and iron fertilization on zinc, iron, manganese and copper content (\%) of direct sown rice

\begin{tabular}{|c|c|c|c|c|c|c|c|c|c|c|c|c|c|c|c|c|}
\hline \multirow{3}{*}{ Treatments } & \multicolumn{4}{|c|}{ Zinc } & \multicolumn{4}{|c|}{ Iron } & \multicolumn{4}{|c|}{ Manganese } & \multicolumn{4}{|c|}{ Copper } \\
\hline & \multirow{2}{*}{ Tillering } & \multirow{2}{*}{$\begin{array}{c}\text { Panicle } \\
\text { initiation }\end{array}$} & \multicolumn{2}{|c|}{ At harvest } & \multirow{2}{*}{ Tillering } & \multirow{2}{*}{$\begin{array}{l}\text { Panicle } \\
\text { initiation }\end{array}$} & \multicolumn{2}{|c|}{ At harvest } & \multirow{2}{*}{ Tillering } & \multirow{2}{*}{$\begin{array}{c}\text { Panicle } \\
\text { initiation }\end{array}$} & \multicolumn{2}{|c|}{ At harvest } & \multirow{2}{*}{ Tillering } & \multirow{2}{*}{$\begin{array}{c}\text { Panicle } \\
\text { initiation }\end{array}$} & \multicolumn{2}{|c|}{ At harvest } \\
\hline & & & Grain & Straw & & & Grain & Straw & & & Grain & Straw & & & Grain & Straw \\
\hline$T_{1}$ & 54 & 47 & 22 & 27 & 428 & 415 & 164 & 383 & 246 & 225 & 72 & 193 & 21 & 18 & 7 & 11 \\
\hline $\mathbf{T}_{2}$ & 64 & 57 & 35 & 40 & 435 & 423 & 191 & 416 & 256 & 242 & 89 & 224 & 29 & 24 & 8 & 15 \\
\hline $\mathbf{T}_{3}$ & 58 & 52 & 30 & 35 & 451 & 435 & 205 & 426 & 255 & 241 & 80 & 220 & 26 & 23 & 9 & 14 \\
\hline $\mathbf{T}_{4}$ & 69 & 62 & 41 & 45 & 466 & 441 & 210 & 431 & 259 & 246 & 94 & 227 & 31 & 28 & 10 & 17 \\
\hline$T_{5}$ & 62 & 54 & 33 & 38 & 432 & 420 & 186 & 415 & 255 & 241 & 82 & 223 & 26 & 23 & 9 & 14 \\
\hline$T_{6}$ & 58 & 50 & 29 & 33 & 450 & 429 & 199 & 422 & 254 & 240 & 80 & 219 & 24 & 21 & 8 & 14 \\
\hline $\mathbf{T}_{7}$ & 67 & 58 & 38 & 43 & 455 & 438 & 207 & 427 & 258 & 244 & 93 & 225 & 30 & 25 & 9 & 17 \\
\hline S.Em ( $( \pm)$ & 2.61 & 2.25 & 1.74 & 1.61 & 5.67 & 3.86 & 3.96 & 3.51 & 12.28 & 11.41 & 5.54 & 9.39 & 2.27 & 1.83 & 0.60 & 1.20 \\
\hline CD $(0.05 \%)$ & 8 & 7 & 5 & 5 & 17 & 12 & 12 & 11 & NS & NS & NS & NS & NS & NS & NS & NS \\
\hline C.V (\%) & 7.36 & 7.22 & 9.23 & 7.52 & 6.12 & 5.41 & 6.47 & 5.56 & 8.36 & 8.24 & 11.39 & 7.36 & 14.71 & 13.69 & 12.36 & 14.21 \\
\hline
\end{tabular}


Table.3 Effect of zinc and iron fertilization on nitrogen, phosphorus and potassium uptake $\left(\mathrm{kg} \mathrm{ha}^{-1}\right)$ of direct sown rice

\begin{tabular}{|c|c|c|c|c|c|c|c|c|c|c|c|c|}
\hline \multirow{3}{*}{ Treatments } & \multicolumn{4}{|c|}{ Nitrogen } & \multicolumn{4}{|c|}{ Phosphorus } & \multicolumn{4}{|c|}{ Potassium } \\
\hline & \multirow[t]{2}{*}{ Tillering } & \multirow{2}{*}{$\begin{array}{l}\text { Panicle } \\
\text { initiation }\end{array}$} & \multicolumn{2}{|c|}{ At harvest } & \multirow[t]{2}{*}{ Tillering } & \multirow{2}{*}{$\begin{array}{l}\text { Panicle } \\
\text { initiation }\end{array}$} & \multicolumn{2}{|c|}{ At harvest } & \multirow[t]{2}{*}{ Tillering } & \multirow{2}{*}{$\begin{array}{l}\text { Panicle } \\
\text { initiation }\end{array}$} & \multicolumn{2}{|c|}{ At harvest } \\
\hline & & & Grain & Straw & & & Grain & Straw & & & Grain & Straw \\
\hline $\mathbf{T}_{1}$ & 40.56 & 60.48 & 52.05 & 36.36 & 5.59 & 11.39 & 13.67 & 7.89 & 52.83 & 82.97 & 29.45 & 74.87 \\
\hline $\mathbf{T}_{2}$ & 59.28 & 77.54 & 85.89 & 53.34 & 8.19 & 16.59 & 21.37 & 13.50 & 73.32 & 112.47 & 44.55 & 98.19 \\
\hline $\mathbf{T}_{3}$ & 52.88 & 71.10 & 80.76 & 47.54 & 7.16 & 14.64 & 18.84 & 11.38 & 67.50 & 102.04 & 41.55 & 91.87 \\
\hline $\mathbf{T}_{4}$ & 68.97 & 88.63 & 98.96 & 62.93 & 10.37 & 19.87 & 28.09 & 17.05 & 81.32 & 153.04 & 51.14 & 110.72 \\
\hline $\mathbf{T}_{5}$ & 55.57 & 73.30 & 82.36 & 49.66 & 7.19 & 15.81 & 19.81 & 12.70 & 69.64 & 106.18 & 42.08 & 94.74 \\
\hline $\mathbf{T}_{6}$ & 51.65 & 69.54 & 79.62 & 47.05 & 8.03 & 14.80 & 18.56 & 11.75 & 66.27 & 98.78 & 39.51 & 90.55 \\
\hline $\mathbf{T}_{7}$ & 63.13 & 83.54 & 87.68 & 54.76 & 9.40 & 18.28 & 23.67 & 14.04 & 77.36 & 129.22 & 47.32 & 99.81 \\
\hline S.Em ( \pm$)$ & 3.71 & 3.83 & 5.94 & 2.34 & 0.68 & 1.22 & 1.74 & 1.08 & 4.54 & 6.50 & 1.56 & 4.03 \\
\hline $\begin{array}{c}\text { CD } \\
(0.05 \%)\end{array}$ & 11.44 & 11.82 & 18.30 & 7.22 & 2.10 & 3.77 & 5.38 & 3.34 & 13.99 & 20.04 & 4.83 & 12.44 \\
\hline C.V (\%) & 11.48 & 8.88 & 12.69 & 8.08 & 14.79 & 13.31 & 14.70 & 14.89 & 11.28 & 10.05 & 6.43 & 7.41 \\
\hline
\end{tabular}


Table.4 Effect of zinc and iron fertilization on zinc, iron, manganese and copper uptake $\left(\mathrm{g} \mathrm{ha}^{-1}\right)$ of direct sown rice

\begin{tabular}{|c|c|c|c|c|c|c|c|c|c|c|c|c|c|c|c|c|}
\hline \multirow{3}{*}{ Treatments } & \multicolumn{4}{|c|}{ Zinc } & \multicolumn{4}{|c|}{ Iron } & \multicolumn{4}{|c|}{ Manganese } & \multicolumn{4}{|c|}{ Copper } \\
\hline & \multirow[t]{2}{*}{ Tillering } & \multirow{2}{*}{$\begin{array}{l}\text { Panicle } \\
\text { initiation }\end{array}$} & \multicolumn{2}{|c|}{ At harvest } & \multirow[t]{2}{*}{ Tillering } & \multirow{2}{*}{$\begin{array}{c}\text { Panicle } \\
\text { initiation }\end{array}$} & \multicolumn{2}{|c|}{ At harvest } & \multirow[t]{2}{*}{ Tillering } & \multirow{2}{*}{$\begin{array}{c}\text { Panicle } \\
\text { initiation }\end{array}$} & \multicolumn{2}{|c|}{ At harvest } & \multirow[t]{2}{*}{ Tillering } & \multirow{2}{*}{$\begin{array}{c}\text { Panicle } \\
\text { initiation }\end{array}$} & \multicolumn{2}{|c|}{ At harvest } \\
\hline & & & Grain & Straw & & & Grain & Straw & & & Grain & Straw & & & Grain & Straw \\
\hline & 117 & 238 & 83 & 159 & 930 & 2123 & 610 & 2232 & 538 & 1156 & 268 & 1131 & 46 & 95 & 28 & 67 \\
\hline$T_{1}$ & & & & & & & & & & & & & & & & \\
\hline $\mathbf{T}_{2}$ & 163 & 325 & 171 & 285 & 1117 & 2425 & 990 & 2963 & 660 & 1392 & 431 & 1594 & 74 & 140 & 43 & 104 \\
\hline $\mathbf{T}_{3}$ & 139 & 283 & 145 & 237 & 1080 & 2396 & 952 & 2905 & 612 & 1328 & 381 & 1494 & 61 & 124 & 40 & 95 \\
\hline $\mathbf{T}_{4}$ & 191 & 377 & 219 & 349 & 1293 & 2708 & 1116 & 3338 & 720 & 1513 & 500 & 1755 & 87 & 172 & 47 & 135 \\
\hline $\mathbf{T}_{5}$ & 150 & 303 & 158 & 261 & 1059 & 2351 & 948 & 2878 & 627 & 1354 & 391 & 1549 & 64 & 130 & 41 & 99 \\
\hline$T_{6}$ & 136 & 273 & 136 & 220 & 1063 & 2334 & 939 & 2867 & 602 & 1306 & 376 & 1487 & 56 & 114 & 39 & 93 \\
\hline $\mathbf{T}_{7}$ & 179 & 346 & 184 & 306 & 1226 & 2614 & 1009 & 3055 & 696 & 1460 & 454 & 1604 & 81 & 152 & 43 & 123 \\
\hline S.Em ( \pm$)$ & 8.73 & 19.52 & 9.65 & 12.01 & 40.85 & 92.17 & 41.64 & 94.90 & 20.90 & 40.71 & 25.79 & 73.42 & 5.71 & 10.90 & 1.98 & 8.64 \\
\hline $\mathrm{CD}(0.05 \%)$ & 27 & 60 & 30 & 37 & 126 & 284 & 128 & 292 & 71 & 125 & 79 & 227 & 18 & 34 & 6 & 27 \\
\hline C.V (\%) & 9.82 & 11.02 & 10.67 & 8.00 & 6.37 & 6.59 & 7.69 & 5.68 & 6.23 & 5.19 & 11.15 & 8.43 & 14.73 & 14.23 & 8.49 & 14.60 \\
\hline
\end{tabular}




\section{Nutrient uptake}

\section{Major nutrient Uptake ( $\left.\mathrm{kg} \mathrm{ha}^{-1}\right)$}

At tillering, panicle initiation, straw and grain at harvest stage the maximum nitrogen uptake (68.97, 88.63, 62.93 and $98.96 \mathrm{~kg} \mathrm{ha}^{-1}$ ), phosphorus uptake $(10.37,19.87,17.07$ and $28.09 \mathrm{~kg} \mathrm{ha}^{-1}$ ) and potassium uptake (81.32, $\left.153.04,110.72,51.14 \mathrm{~kg} \mathrm{ha}^{-1}\right)$ was recorded under RDF+ ZnSO $@$ @50kg ha ${ }^{-1}+\mathrm{FeSO}_{4} @ 25 \mathrm{~kg}$ $\mathrm{ha}^{-1}$ through soil application. The lowest nitrogen, phosphorus and potassium uptake was recorded with RDF (Table 3). The combined soil or foliar application of zinc and iron increased higher nutrient uptake at all stages of crop growth. The higher nutrient uptake may be attributed to enhanced nutrient availability with the external application of micronutrients. Due to the steady and continuous availability of nitrogen in the rhizosphere coupled with enhanced dry matter production resulted in higher uptake of nitrogen. These results were in confirmity with those of Mujumdar et al., (2007). The higher P uptake might be due to the solubilization of native phosphorus by the inorganic acids under reduced conditions in addition to applied fertilizers which ultimately resulted in better root growth and increased physiological activity of roots to absorb more phosphorus. Elayaraja and Singaravel, 2012. The massive increase in potassium uptake due to the interaction of $\mathrm{K}$ and $\mathrm{Zn}$ by the improvement of enzymatic activity and metabolic processes of plant, which might have ultimately facilitated the removal of potassium and consequently the yield. These results was in accordance with those of Khan et al., (2003).

\section{Micronutrient Uptake ( $\mathrm{g} \mathrm{ha}^{-1}$ )}

At tillering, panicle initiation, straw and grain at harvest stage the highest zinc uptake $(191,377$, 349 and $\left.219 \mathrm{~g} \mathrm{ha}^{-1}\right)$, iron uptake (1293, 2708, 3338 and $\left.1116 \mathrm{~g} \mathrm{ha}^{-1}\right)$, manganese uptake (720, 1513, 1755 and $500 \mathrm{~g} \mathrm{ha}^{-1}$ ) and copper uptake (87, 172, 135 and $\left.47 \mathrm{~g} \mathrm{ha}^{-1}\right)$ was recorded under $\mathrm{RDF}+\mathrm{ZnSO}_{4} @ 50 \mathrm{~kg} \mathrm{ha}^{-1}+\mathrm{FeSO}_{4} @ 25 \mathrm{~kg} \mathrm{ha}^{-1}$ through soil application. The lowest micronutrient uptake was recorded with RDF (Table 4). The uptake being the product of content and dry matter production, the increase in $\mathrm{Zn}$ uptake by the crop might be due to easy availability of $\mathrm{Zn}$ with higher concentrations and rapid rate of absorption caused by greater mobility of zinc when applied through soil. The present findings are in conformity with the findings of Yadav et al., (2011). Application of higher level of zinc significantly increased the $\mathrm{Zn}$ uptake by both straw and grain. These results are in agreement with those Gohil et al., (2017). The superiority of treatments might be due to combined application of zinc and iron nutrients as basal or foliar applications along with RDF through which required nutrients were available to the crop throughout growth period at required quantities and so enhanced the nutrient uptake. The increased manganese and copper uptake might be due to zinc and iron fertilization, which might be have increased the manganese availability through enhanced mineralization and chelation action which facilitated greater absorption and utilization of manganese by the plants Latha et al., (2002) and Sumangala (2003).

\section{References}

Antil, R. S., Dahia, S. S and Bhandari, D. K. 1989. Effect of zinc and manganese application on dry matter yield and uptake of nutrients in paddy (Oryza sativa L.) under upland and lowland conditions. Haryana Agricultural University Journal of Research. 3: 197204.

Elayaraja, D and Singaravel, R. 2012. Zinc and boron application on groundnut yield and nutrient uptake in coastal sandy soils. Asian Journal of Soil Sciences. 7(1): 50-53.

Farooq, M., Siddique, K.H.M., Rehman, H., Aziz, T., Dong-Jin, Lee and Wahid, A. 2011. Rice direct seeding, Experiences, Challenges and opportunities. Soil Tillage Research. 111(2) : 87-98.

Ghoneim, A.M. 2016. Effect of Different Methods of $\mathrm{Zn}$ Application on Rice 
Growth, Yield and Nutrients Dynamics in Plant and Soil. Journal of Agriculture and Ecology Research. 6(2): 1-9.

Gohil, N.B., Patel, D.P., Patel, B. A and Patha, O. I. 2017. Effect of soil application of Fe and $\mathrm{Zn}$ on nutrient content and uptake by two rice varieties. International Journal of Chemical Studies. 5(2): 396400.

Keram, K.S., Sharma, B.L and Sawarkar, S.D. 2012. Impact of $\mathrm{Zn}$ application on yield, Quality, Nutrients uptake and soil fertility in a medium deep black soil (Vertisol). International Journal of Science, Environment and Technology. 1(5):563 - 571.

Khan, M.U., Qasim, M., Subban, M., Ahmad, R and Ali, L. 2003. Effect of zinc application by different methods on the chemical composition and grain quality of rice. Pakistan Journal of Applied Sciences. 3(7): 530-536.

Latha, M.R., Savithri, P., Indrani, R and Kamraj, S. 2002. Residual effect of zincenriched organic manures on yield and zinc uptake in sunflower under maizesunflower cropping sequence. Agriculture Science Digest. 2(22): 114116.

Majumdar, B., Venkatesh, M.S and Saha, R. 2007. Effect of nitrogen, farmyard manure and non-symbiotic nitrogenfixing bacteria on yield uptake and soil fertility in upland rice. Indian Journal of Agricultural Sciences. 77(6): 335-339.

Rengel, Z., Batten, G.D and Crowley, D.E.
1999. Agronomic approaches for improving the micronutrient density in edible portions of field crops. Field Crops Research. 60:27-40.

Singh, M.V. 2009. Micronutrient nutrition problems in soils of India and improvement for human and animal health. Indian Journal of Fertilizers. 5 (4):11-16.

Sumangala, B.J. 2003. Response of groundnut (Arachis hypoaea L.) to conjunctive and bio-inoculants at graded levels of fertilizers under dryland conditions. $\mathrm{Ph} . \mathrm{D}$. Thesis, University of Agricultural Sciences, Bengaluru, Karnataka (India).

Tahir, M and Kausar, M.A. 1994. Fertilizer zinc efficiency for rice and subsequent wheat as affected by urea and manure application. National Congress of Soil Science. 347-354.

Viraktamath, B.C., Bentur, J.S., Rao, K.V and Sain, M. 2011. Rice Scenario. Vision 2030. Directorate of Rice Research Rajendranagar, Hyderabad. pp 1.

Yadav, G. S., Shivay Y. S and Kumar, D. 2011. Effect of mulching and iron nutrition on productivity, nutrient uptake and economics of aerobic rice (Oryza sativa). Indian Journal of Agronomy. 56 (4): $365-372$.

Zhao, L., Wu, M and Li, Y. 2011. Nutrient uptake and water use efficiency as affected by modified rice cultivation methods with irrigation. Paddy Water Environment. 9:25-32.

\section{How to cite this article:}

Janardhan, S. and Usha Rani, I. 2019. Effect of Zinc and Iron Fertilization on Yield, Nutrient Content and Uptake of Direct Sown Rice. Int.J.Curr.Microbiol.App.Sci. 8(10): 1226-1234. doi: https://doi.org/10.20546/ijcmas.2019.810.144 